\title{
Seed Delivery Systems and Farm Characteristics Influencing the Improved Seed Uptake by Smallholders in Northern Ghana
}

\author{
Eunice Etwire ${ }^{1}$, Anoma Ariyawardana ${ }^{1} \&$ Miranda Y. Mortlock ${ }^{1}$ \\ ${ }^{1}$ School of Agriculture and Food Sciences, The University of Queensland, Gatton, QLD, 4343, Australia \\ Correspondence: Eunice Etwire, Department of Agriculture, P.O.Box 43, Mampongteng, Kwabre East, Ghana. \\ Tel: 233-502-417-701. E-mail: eunice.etwire@gmail.com
}

Received: February 15, 2016

doi:10.5539/sar.v5n2p27
Accepted: March 1, 2016 Online Published: April 5, 2016

URL: http://dx.doi.org/10.5539/sar.v5n2p27

\begin{abstract}
The utilisation of improved seeds is reliant on distribution system and farmers' preferences in using the seed. Primary data were collected from key informant interviews in seed delivery chains and a farmer survey to analyse the northern Ghanaian seed delivery systems and factors influencing the adoption of improved seed by farmers. The seed system in Ghana is made up of three main components; a formal seed system, an informal farmers' seed system and a quasi-formal seed system. The seed chain starts with breeder seed production by Council for Scientific and Industrial Research (except for imported seed) and ends with the grain farmer as the final consumer. The communication flows between members, strength of relationships and farm characteristics reveled to be affecting the improved seed uptake by smallholders in Northern Ghana. The study highlights the value of strengthening the seed delivery system and improving the availability and accessibility of improved seed varieties.
\end{abstract}

Keywords: adoption of improved maize varieties, certified seed, farmer preferences, seed delivery system, smallholder farmers, northern Ghana

\section{Introduction}

The role of seeds as an agricultural input technology cannot be underestimated as it is an indispensable input in any agricultural production system (Almekinders \& Louwarrs, 2008). Seeds are the most important input in any crop-based farming system (Muthoni \& Nyamongo, 2008; Tripp, 2003; Mc Guire, 2001; Cromwell, 1996; Almekinders \& De Boef, 2000). Seed quality determines the overall grain yield and the market value of the final product (Louwaars \& De Boef, 2012). Hence, improved seed could be considered as the most important technology that substantially contributes towards crop productivity irrespective of other inputs (Cromwell, Friis-Hansen, \& Turner, 1992).

Traditionally in Ghana, seeds were either exchanged from farmer-to-farmer or were sourced from local markets (Cromwell, Friis-Hansen, \& Turner, 1992). Over time formal seed delivery systems have emerged, however the traditional or informal seed delivery systems are still in existence in most parts of Ghana (Almekinders \& De Boef, 2000; Cromwell, 1996; Loch \& Boyce, 2003; Mc Guire, 2001; Ndjeunga, 2002; Rao, 2004). This informal seed system describes the process where farmers acquire seeds from traditional sources based on seed exchange or gift or purchase from other farmers and local markets (Pandey et al., 2011). Comparatively, the informal seed system is not characterised, regulated and supervised by any private or public institution but dominated by smallholder farmers (Etwire et al., 2013a). The informal seed system comprises about 80 percent of the total seed system for most staple crops in Ghana (Louwaars \& Boef, 2012). Within this informal system, seed varieties are selected, multiplied and distributed at the local level based on traditional knowledge (Etwire et al., 2013a). According to Pandey et al. (2011), smallholder farmers combine different crops and manage to maintain the genetic diversity usually consisting of the traditional landraces.

In contrast to the informal seed distribution system, the formal seed system notably ensures the development and distribution of improved seed varieties through a series of interdependent activities. Muthoni and Nyamongo (2008) loosely describe the formal seed system as a set of organisations made up of national research institutes, seed companies, extension programs and non-governmental organisations (NGOs) involved in the production and distribution of certified seed varieties. This definition fails to emphasize on the linkages or interactions between the institutions and the support involved in the production and marketing of seed. Loch and Boyce 
(2003) provide a more complex description that captures the essential characteristics of the formal seed system. They define the formal seed system as a framework of institutions linked together through a combination of components and processes of production, multiplication, storage and marketing of improved varieties of specific quality along with the interactions and support to make seed available to a particular end user (Loch \& Boyce, 2003). Hence, the formal seed system may be characterised by a chain of longitudinal integration of activities from germplasm manipulation and selection to purchasing of seed by final customers (farmers) through successive generations (Cromwell, Friis-Hansen, \& Turner, 1992).

Hybrid seed system is an emerging seed distribution system in Ghana where the community seed production is being promoted by development projects to compliment the formal seed system and thereby making improved seeds accessible to local communities (Louwaars \& De Boef, 2012; Etwire et al., 2013a). These projects access certified foundation seeds from the formal system and pass them to farmer groups based locally (Etwire et al., 2013a). Usually, these farmer groups receive chemical inputs and capacity building support from the projects and the associated costs are repaid after selling their harvest. Thereby, this system aims to improve farmer's access to certified seeds (Etwire et al., 2013a).

Despite the interventions in developing a formal seed distribution system in Ghana, it has been noted that the formal seed delivery system has not lived up to expectations in terms of ensuring effective delivery of certified seeds to smallholder farmers (Cromwell, Friis-Hansen, \& Turner, 1992). Within the formal seed delivery system, more emphasis has been placed on developing the physical aspects such as breeding new seed varieties, multiplication, processing, storage and marketing rather than addressing key institutional issues that can assist the system to perform effectively (Niangado, 2010; Cleaver, 1993). There also appears to be little interaction and communication among various actors within the seed delivery chain in northern Ghana which has resulted in a weak system that supplies less than 20 percent of the seed requirement of farmers (Etwire et al., 2013a; Tripp \& Mensah-Bonsu, 2013). Even though similar actors on different seed delivery channels have similar goals, they appear to be operating in isolation resulting in duplication and dissipation of effort. Smallholder farmers play a key role in the adoption process of certified seed varieties for cultivation (Tripp, 2006). However, there is little documentation of smallholder farmers' preferences for a particular seed crop variety in Ghana (Tripp \& Mensah-Bonsu, 2013; Horna \& Nagarajan, 2010). Consequently, this may have led to the persistent absence of alternatives in providing efficient seed delivery services to smallholder farmers (Cromwell, Friis-Hansen, \& Turner, 1992).

Furthermore, most agricultural development projects implemented in Ghana have placed less attention in facilitating seed delivery to poor smallholder farmers as compared to other inputs such as fertilizers and pesticides (Louwaars \& De Boef, 2012). The seed delivery system is subject to constraints which reduce the ability to reach smallholders. There are untapped opportunities within the seed delivery system that could be harnessed to improve the performance of the distribution system. However, these constraints and opportunities have not been well documented and prioritized. This study explores how the formal seed delivery system in northern Ghana operates and using maize as an example it identifies the factors that influence the adoption of improved seeds. The specific aims of this study are to:

(1) map the key players, their goals, functions, relationships and the flow of information in the seed delivery system in northern Ghana,

(2) rank smallholder farmer preferences for improved maize seeds, and

(3) identify the factors that influence the level of adoption of improved maize seeds.

Through the first objective, this study aims to provide a snapshot view of the five common staple crops' - maize, groundnut, cowpea, sorghum and millet - seed delivery system in northern Ghana. This includes an identification of various actors and the relationships between them. The study will therefore make an empirical contribution to the literature on seed systems in Ghana. Through the second and third objectives, this study specifically focuses on maize and identifies the smallholder farmer preferences and factors that influence the level of adoption of improved seeds varieties. An understanding of specific farmer related factors are crucial in bridging the researcher-farmer gap and thereby to improve the utilisation of improved seed varieties.

\section{Method}

\subsection{Study Area}

Northern Ghana (Northern Region, Upper East Region and Upper West Region) was purposively selected because it is one of the intervention areas of the project, "Unlocking the opportunities for a sustainable seed system in West Africa" which was funded by Australian Aid, coordinated by the West and Central African 
Council for Agricultural Research and Development (CORAF/WECARD) and implemented in Ghana by CSIR-SARI (Council for Scientific and Industrial Research). A map of the study area is shown in Figure 1 below.

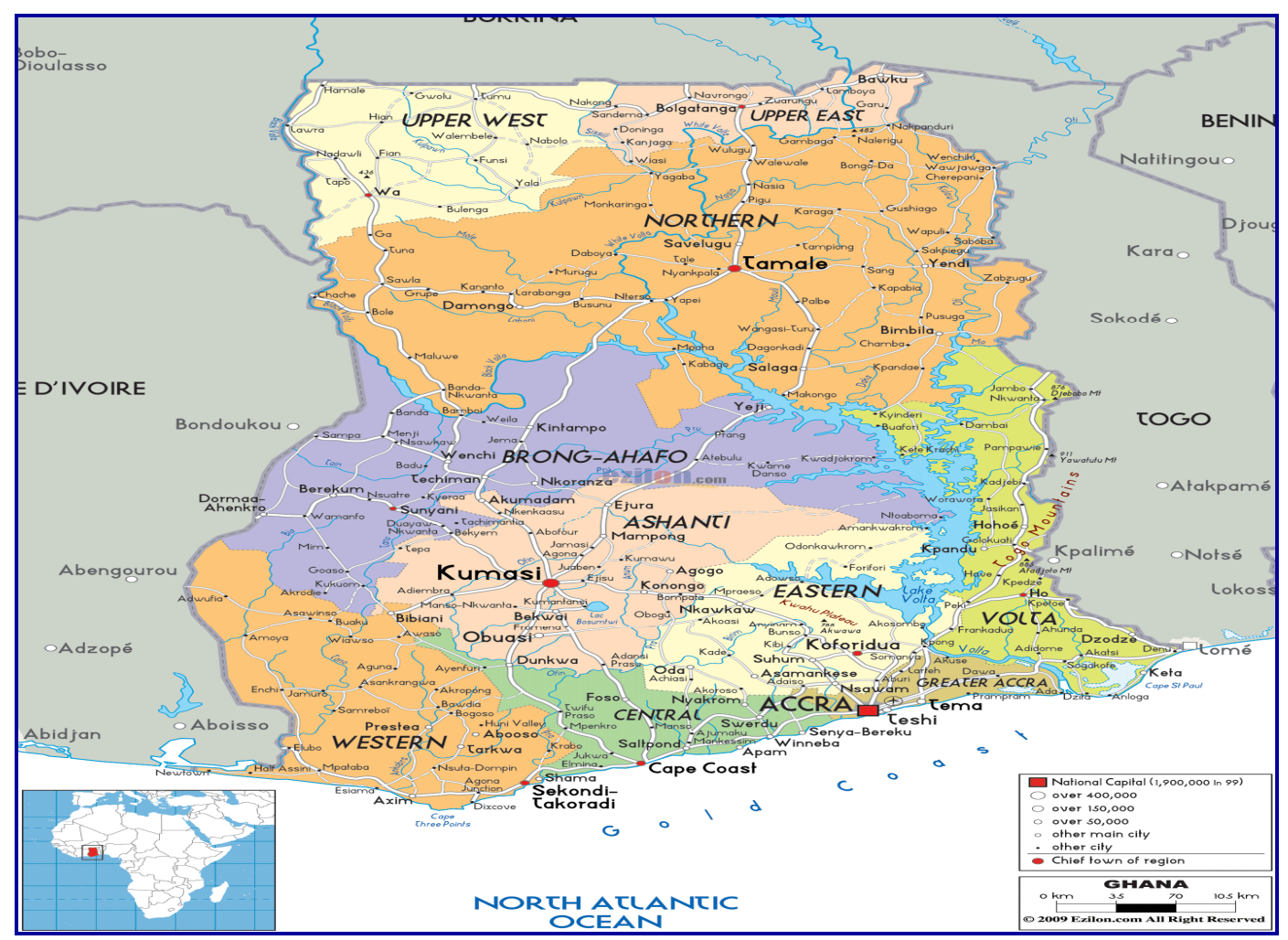

Figure 1. Administrative map of Ghana (Ghana Statistical Service, 2011)

\subsection{Data and Data Sources}

Primary data were collected through field surveys in two stages. The first stage involved in-depth discussions with various actors within the seed delivery system. Five topic guides were developed for this study and the required ethical clearance was obtained from the Research Committee of the School of Agriculture and Food Sciences, the University of Queensland. These topic guides were used to guide the discussions with research scientists at the Savanna Agricultural Research Institute of the Council for Scientific and Industrial Research (CSIR-SARI) $(n=2)$, seed distributors $(n=14)$, Ghana Seed Inspection Division (GSID) $(n=2)$, seed companies $(n=5)$, registered seed producers $(n=12)$, community seed growers $(n=8)$, and finally the grain farmers $(n=204)$. All actors within the seed delivery system, with the exception of grain farmers, were identified through snowball sampling technique. Grain farmers were identified through a multi stage sampling technique. In accordance with the ethical requirement, each survey participant who willingly volunteered to participate endorsed a consent form. The discussions were centered on understanding the functions, relationships and flow of information in the seed delivery system with respect to maize, groundnut, cowpea, sorghum and millet.

The second stage of the data collection involved a survey of maize farmers to understand their utilization patterns, preferences, costs, accessibility and seed quality and their socio-economic characteristics. In addition, farmers were also asked to rank the factors that affect farmer's preference for certified seeds. Ten factors were identified based on a literature review and a reconnaissance field visit during the preparatory stage of the survey. These factors include seed availability, affordability, availability of grain market, pest and disease resistance, grain price or profitability, seed packaging, taste and nutrition, grain size, fertilizer requirement and maturity period. A detailed questionnaire was designed to gather specific information from farmers and was pre-tested upon obtaining the ethical clearance. Using a simple random sampling technique, three districts in Northern Region and two districts each in Upper East and West regions and ten communities in Northern Region and five communities each in Upper East and West regions were selected. Ten grain farmers were randomly selected from 
each of these communities. The study recruited experienced staff from CSIR-SARI whom had been trained before embarking on data collection. In total, 204 questionnaires were completed in January 2014 through a household survey.

\subsection{Method of Analysis}

Based on the qualitative data gathered through in-depth discussions value exchanges were mapped as a flow diagram showing goods and services, knowledge flow and creation of intangible value. Value is not only limited to producing and selling seeds but also developing linkages (Baig \& Akhtar, 2011). Therefore, by adopting value chain assessment tools, functions, relationships and information flows that exist between different actors were identified and mapped.

Farmer rankings on preferences on certified seeds were analysed by using Kendall's Coefficient of Concordance. Thereby the null hypothesis 'there is no agreement between grain farmers on their rankings' was tested. The socio-economic characteristics of farmers were analysed using descriptive statistics, which were disaggregated based on adopters and non-adopters of improved maize varieties. Then, the factors influencing adoption of improved maize varieties were analysed by using logistic regression. According to Greene (2003), the decision to adopt could be explained based on random utility. Farmers will therefore adopt an improved maize variety if it provides them more satisfaction relative to a traditional maize variety. Analysis was undertaken in SPSS version (ABM Corp, 2013).

According to Gujarati (2004), the probability that a farmer will adopt an improved maize seed variety can be represented with equation (1);

$$
P_{i=} \frac{1}{1+e^{-z_{i}}}=\frac{e^{z}}{1+e^{z}}
$$

Where $Z_{i}=\beta_{1}+\beta_{2} X_{i}$

Similarly, the probability of a farmer not adopting an improved maize seed variety can also be represented with equation (2);

$$
1-P=\frac{1}{1+e^{Z_{i}}}
$$

Therefore, the odds ratio of a farmer adopting an improved maize seed variety can be computed with equation (3)

$$
\frac{P_{i}}{1-P_{i}}=\frac{1+e^{Z_{i}}}{1+e^{-Z_{i}}}=e^{Z_{i}}
$$

Taking the natural log of equation (3) yields;

$$
L_{i}=\ln \left(\frac{P_{i}}{1-P}\right)=B_{1}+B_{2} X_{i}
$$

Where $B_{1}$ and $B_{2}$ are parameter estimates and $X i$ are a set of explanatory variables (Table 1). The study relies on marginal effects for discussion instead of the coefficient estimates since it provides both magnitude and direction of change. The empirical model estimated by the study is presented as equation (5);

$$
\begin{aligned}
& Y=\mathrm{B}_{0}+\mathrm{B}_{1} U E R+\mathrm{B}_{2} U W R+\mathrm{B}_{3} \text { Gend }+\mathrm{B}_{4} \text { Educ }+\mathrm{B}_{5} \text { HHSize }+\mathrm{B}_{6} 1000 \text { Inc }+\mathrm{B}_{7} 1500 \text { Inc }+ \\
& \mathrm{B}_{8} 2000 \text { Inc }+\mathrm{B}_{9} 2500 \text { Inc }+\mathrm{B}_{10} \text { Fmsize }+\mathrm{B}_{11} \text { CertCowp }
\end{aligned}
$$


Table 1. Description of the variables used in the logistic model

\begin{tabular}{lll}
\hline Variable & Description & Unit of Measurement \\
\hline UER & Located in Upper East Region & Dummy variable; $1=$ Yes, $0=$ Otherwise \\
UWR & Located in Upper West Region & Dummy variable; $1=$ Yes, $0=$ Otherwise \\
Gend & Gender of grain farmer & Dummy variable; $1=$ Male, $0=$ Female \\
Educ & Had formal education & Dummy variable; $1=$ Yes, $0=$ Otherwise \\
HHSize & Household size & Number \\
1000Inc & Annual income is less than GH $\phi 1000$ & Dummy variable; $1=$ Yes, $0=$ Otherwise \\
1500Inc & Annual income of GH $\not 1001-1500$ & Dummy variable; $1=$ Yes, $0=$ Otherwise \\
2000Inc & Annual income of GH $\not 1501-2000$ & Dummy variable; $1=$ Yes, $0=$ Otherwise \\
$2500 I n c$ & Annual income of GH $\not 2001-2500$ & Dummy variable; $1=$ Yes, $0=$ Otherwise \\
Fmsize & Farm size & Hectares \\
CertCowp & Cultivates certified cowpea seed & Dummy variable; $1=$ Yes, $0=$ Otherwise \\
\hline
\end{tabular}

\section{Results and discussion}

Analysis of the data shows that the formal and quasi-formal seed systems in northern Ghana is characterised by multiple seed delivery channels as shown in Figure 2. Breeder seed is produced within the formal seed system, and multiplied to produce foundation seed. Foundation seed is further multiplied to produce certified seed for sale to grain farmers. Ghana Seed Inspection Division (GSID) of Ministry of Food and Agriculture is the agency responsible for seed certification. Analysis of the data shows that two institutes of the Council for Scientific and Industrial Research (CSIR), which are, Savanna Agricultural Research Institute (SARI) and Crops Research Institute (CRI) are the main sources of breeder and foundation seeds utilized by seed companies, registered seed producers and community seed growers to produce certified seeds in northern Ghana. The Grains and Legumes Development Board (GLDB) was also found to be an important source of foundation seed. The following formal and semi-formal seed delivery channels were identified in northern Ghana:

(1) Imported seed is the only seed delivery channel that does not start with the breeder seed, by multinational companies such as WIENCO. CSIR is then contracted to conduct field trials in order to generate relevant local data for certification purposes. After certification, the imported seed is then sold to grain farmers through seed distributors

(2) Breeder seed produced by CSIR and used to produce foundation seed.

(3) Seed companies use foundation seed and multiply up to certified seed and sell to farmers.

(4) Seed companies recruit farmers as out-growers for the certified seed production. It is bought by the seed companies and resold to farmers. Community seed production in this sense can be viewed as a seed company having large tracts of land and recruiting farmers as growers.

(5) NGOs and projects to procure foundation seed from either CSIR or GLDB and recruit lead farmers as community seed growers and then provide them with inputs and capacity building to produce certified seed. The certified seed produced is then absorbed by the NGO or project and subsequently sold or donated to their target farmers.

(6) The distribution of imported seed to victims of disasters such as floods, drought and wild fires. Relief agencies such as the National Disaster Management Organisation (NADMO) and some NGOs are able to access seed aid from foreign countries or donors in times of disaster which is subsequently distributed to grain farmers.

Promotion of the use of certified seed among farmers appears to be one area of intervention that is receiving a lot of attention. In a bid to make certified seed readily available to their target farmers, NGOs procure seeds from CSIR. According to Almekinders (2000), seed relief and external seed sources are a threat to the development of the local seed system. For example, the local economy and genetic diversity may be undermined.

Policy, finance and transport are cross cutting issue affecting the seed delivery system in northern Ghana. The Plants and Fertilizer Act, Act 803, was passed by the parliament of Ghana in 2010. The Act addresses issues of seeds, plant protection and fertilizer control. With respect to seed, the Act addresses pertinent issues on the registration of seed importers and exporters, production and marketing, quality control and the establishment of a national seed council. Firstly finance and then transport appears to be critical for certified, foundation and 
breeder seed production. Whereas breeder seed development is dependent on donor funds and grants, foundation and breeder seed production depends on loans and savings. Transport plays an important role in moving seed from the breeders to certified seed producers. Transport also plays a critical role in making certified seeds available to grain farmers.

\subsection{Key Players, Their Goals, Functions, Relationships and Information Flow in the Seed Delivery System}

The key players in the seed delivery system in northern Ghana are CSIR, seed companies, registered seed producers, community seed growers, seed distributors, NGOs, relief organisations, GSID and grain farmers. The various players are discussed below.

\subsubsection{Council for Scientific and Industrial Research (CSIR)}

The Savanna Agricultural Research Institute, is one of the 13 research institutes of the CSIR which is located in northern Ghana. The core mandate of CSIR-SARI is to conduct research into food and fibre crops in order to increase productivity of farmers in northern Ghana. CSIR-SARI conducts its research through a multidisciplinary farming systems approach. Their information flows directly from extension arm of Ghana Seed Inspection Division (GSID) of the Ministry of Food and Agriculture (MoFA) and farmers leading to establishment of good relationships. Between the seed companies and registered seed producers the information flow is adversarial, especially in the sale of foundation seed leading to poor relationships.

\subsubsection{Seed Companies}

Establishment and operation of seed companies by entrepreneurs is a relatively new venture in northern Ghana. None of the seed companies in northern Ghana has employed the services of a seed breeder or has the capacity to process their own seed. They all depend on processing facilities at the Ministry of Food and Agriculture. Even though access to long-term finance appears to be a challenge, certified seed production by seed companies is relatively mechanised as compared to other seed producers. It was observed that seed companies cultivate the largest area (about $104 \mathrm{Ha}$ ) of land and they were headed by educated males. Seed companies work very closely with CSIR, MoFA and farmers in implementing donor funded projects and hence have established good relationships. There is a regular information flow to and from research and extension agents in terms of sharing new improved varieties and good agricultural practices.

\subsubsection{Registered Seed Producers}

All registered seed producers interviewed were males who were mostly heads of their households. About a third of them were educated and the average seed field size was 7 hectares. Registered seed producers are interested in producing seeds and make them readily available to grain farmers and to maximise their profits. Analysis of the data shows that these registered seed producers have purely price-based relationships with both CSIR and GLDB in purchasing foundation seeds. However, it was revealed that they develop very good relationships when they are working on donor funded projects. In contrast, they have built stronger relationships with GSID, seed distributors and some farmers during the process of selling certified seeds.

\subsubsection{Seed Distributors}

Seed distributors have a good relationship with seed companies and registered seed producers. They cooperate with each other and are in constant communication with the seed growers especially during the rainy season. Seed distributors serve as a link between seed growers and grain farmers by either communicating the characteristics of certified seed or providing feedback on their performance.

\subsubsection{Non-Governmental Organisations and Relief}

Non-governmental organisations and relief projects have good relationships with donors, grain farmers, CSIR and MoFA with information flow being both ways.

\subsubsection{Community Seed Growers}

Community seed growers have good relationships with smallholder grain producers, seed companies and NGOs or projects. There is also healthy communication and information flows among them since they are directly involved with the NGOs or a project where they constantly interact.

\subsubsection{Ghana Seed Inspection Division (GSID)}

The main goal of this division is to inspect and certify the production and sale of foundation and certified seed. They are also responsible for regulating seed importation and exports as well as field inspection and laboratory testing of seeds. GSID manufactures and sell plain packaging materials to seed producers. Information about the seed and source of seed is usually printed on a sheet of paper and inserted into the bag by seed growers. The 
GSID directly communicate with Seed Producers Association of Ghana, (SEEDPAG) through Research Extension and Linkage Committees (RELC) meetings where they interact and share any information on seed availability and discuss constraints in the formal seed delivery system.

\subsubsection{Grain Farmers}

Grain farmer's goal is to increase farm productivity and incomes, and they use certified seed. Grain production is mostly undertaken by smallholder, subsistent and rain-fed farmers under low levels of mechanisation. They have strong relationships with each other as well as with MoFA and through the extension agents. Grain farmers receive information from various actors in the seed delivery system as well as from radio.

Table 2. Characteristics of various actors within the seed delivery system

\begin{tabular}{|c|c|c|c|c|}
\hline $\begin{array}{l}\text { Key Player/ } \\
\text { Actor }\end{array}$ & Goal & Functions & Relationship & Information flow \\
\hline $\begin{array}{l}\text { CSIR/ } \\
\text { Researchers }\end{array}$ & $\begin{array}{l}\text { The core mandate of } \\
\text { CSIR-SARI is to conduct } \\
\text { research into food and fibre } \\
\text { crops in order to increase } \\
\text { productivity of farmers in } \\
\text { northern Ghana }\end{array}$ & $\begin{array}{l}\text { Breeding of new varieties. } \\
\text { Adaptation of existing } \\
\text { varieties. } \\
\text { Production of foundation } \\
\text { seed. } \\
\text { Capacity building services. }\end{array}$ & $\begin{array}{l}\text { Good relationships with } \\
\text { extension agents and } \\
\text { farmers. } \\
\text { Adversarial relationships } \\
\text { with the rest of the chain } \\
\text { members. }\end{array}$ & $\begin{array}{l}\text { Direct flow of information to } \\
\text { extension agents and grain } \\
\text { producers. } \\
\text { Some information flow to } \\
\text { seed companies and } \\
\text { registered seed producers } \\
\text { especially on donor funded } \\
\text { projects. }\end{array}$ \\
\hline $\begin{array}{l}\text { Seed } \\
\text { companies }\end{array}$ & $\begin{array}{l}\text { Increase sales, Maximize } \\
\text { profits, Legal recognition }\end{array}$ & Certified seed production & $\begin{array}{l}\text { Good relationships with } \\
\text { research, extension agents } \\
\text { and farmers }\end{array}$ & $\begin{array}{l}\text { Regular information flow to } \\
\text { and from research and } \\
\text { extension agents. }\end{array}$ \\
\hline $\begin{array}{l}\text { Registered } \\
\text { seed } \\
\text { producers }\end{array}$ & $\begin{array}{l}\text { Maximizing profits and } \\
\text { making seeds readily } \\
\text { available to grain farmers }\end{array}$ & $\begin{array}{l}\text { Production, promotion and } \\
\text { provision of extension } \\
\text { services on certified seed } \\
\text { use. }\end{array}$ & $\begin{array}{l}\text { Price-based discussions } \\
\text { with research, Grains and } \\
\text { Legumes Development } \\
\text { Board, seed distributors } \\
\text { and grain farmers. }\end{array}$ & $\begin{array}{l}\text { Reciprocal information flow } \\
\text { to extension agents, research, } \\
\text { Grains and Legumes } \\
\text { Development Board, seed } \\
\text { distributors and grain farmers. }\end{array}$ \\
\hline $\begin{array}{l}\text { Seed } \\
\text { distributors }\end{array}$ & $\begin{array}{l}\text { Maximise sales by reaching } \\
\text { several farmers with } \\
\text { genuine agro inputs } \\
\text { including certified seed }\end{array}$ & $\begin{array}{l}\text { Agro input distribution and } \\
\text { general advice on the use of } \\
\text { their products }\end{array}$ & $\begin{array}{l}\text { Good relationships with } \\
\text { seed companies, } \\
\text { registered seed producers } \\
\text { and grain farmers }\end{array}$ & $\begin{array}{l}\text { Serve as a link between } \\
\text { research and grain farmers }\end{array}$ \\
\hline $\begin{array}{l}\text { NGOs and } \\
\text { Relief }\end{array}$ & $\begin{array}{l}\text { Ensuring food security, } \\
\text { poverty alleviation as well } \\
\text { as emergency relief }\end{array}$ & $\begin{array}{l}\text { Capacity building activities, } \\
\text { on-farm demonstration of } \\
\text { use of certified seed, } \\
\text { advocacy and lobby, } \\
\text { provision of grants and } \\
\text { mentorship }\end{array}$ & $\begin{array}{l}\text { Good relationships with } \\
\text { donors, grain farmers, } \\
\text { research and extension }\end{array}$ & $\begin{array}{l}\text { Reciprocal information flow } \\
\text { with donors, grain farmers, } \\
\text { research and extension }\end{array}$ \\
\hline $\begin{array}{l}\text { Community } \\
\text { seed growers }\end{array}$ & $\begin{array}{l}\text { Promote good agronomic } \\
\text { practice and produce good } \\
\text { quality seed }\end{array}$ & Certified seed production & $\begin{array}{l}\text { Good relationship with } \\
\text { grain farmers, seed } \\
\text { companies and NGOs or } \\
\text { project }\end{array}$ & $\begin{array}{l}\text { Healthy communication and } \\
\text { information flow with grain } \\
\text { farmers, seed companies and } \\
\text { NGOs or project }\end{array}$ \\
\hline $\begin{array}{l}\text { Ghana Seed } \\
\text { Inspection } \\
\text { Division }\end{array}$ & $\begin{array}{l}\text { Inspect and certify the } \\
\text { production and sale of } \\
\text { foundation and certified } \\
\text { seed }\end{array}$ & $\begin{array}{l}\text { Registration of seed growers } \\
\text { and seed dealers Regulating } \\
\text { seed importation and } \\
\text { exports }\end{array}$ & $\begin{array}{l}\text { Good relationships with } \\
\text { seed growers, research } \\
\text { and extension }\end{array}$ & $\begin{array}{l}\text { Information flows to seed } \\
\text { growers, research and } \\
\text { extension }\end{array}$ \\
\hline Grain farmers & $\begin{array}{l}\text { Increase farm productivity } \\
\text { and incomes }\end{array}$ & Grain production & $\begin{array}{l}\text { Good relationships with } \\
\text { researchers, seed } \\
\text { distributors, seed growers } \\
\text { and NGOs }\end{array}$ & $\begin{array}{l}\text { Information flow from } \\
\text { researchers, seed distributors, } \\
\text { seed growers and NGOs }\end{array}$ \\
\hline
\end{tabular}



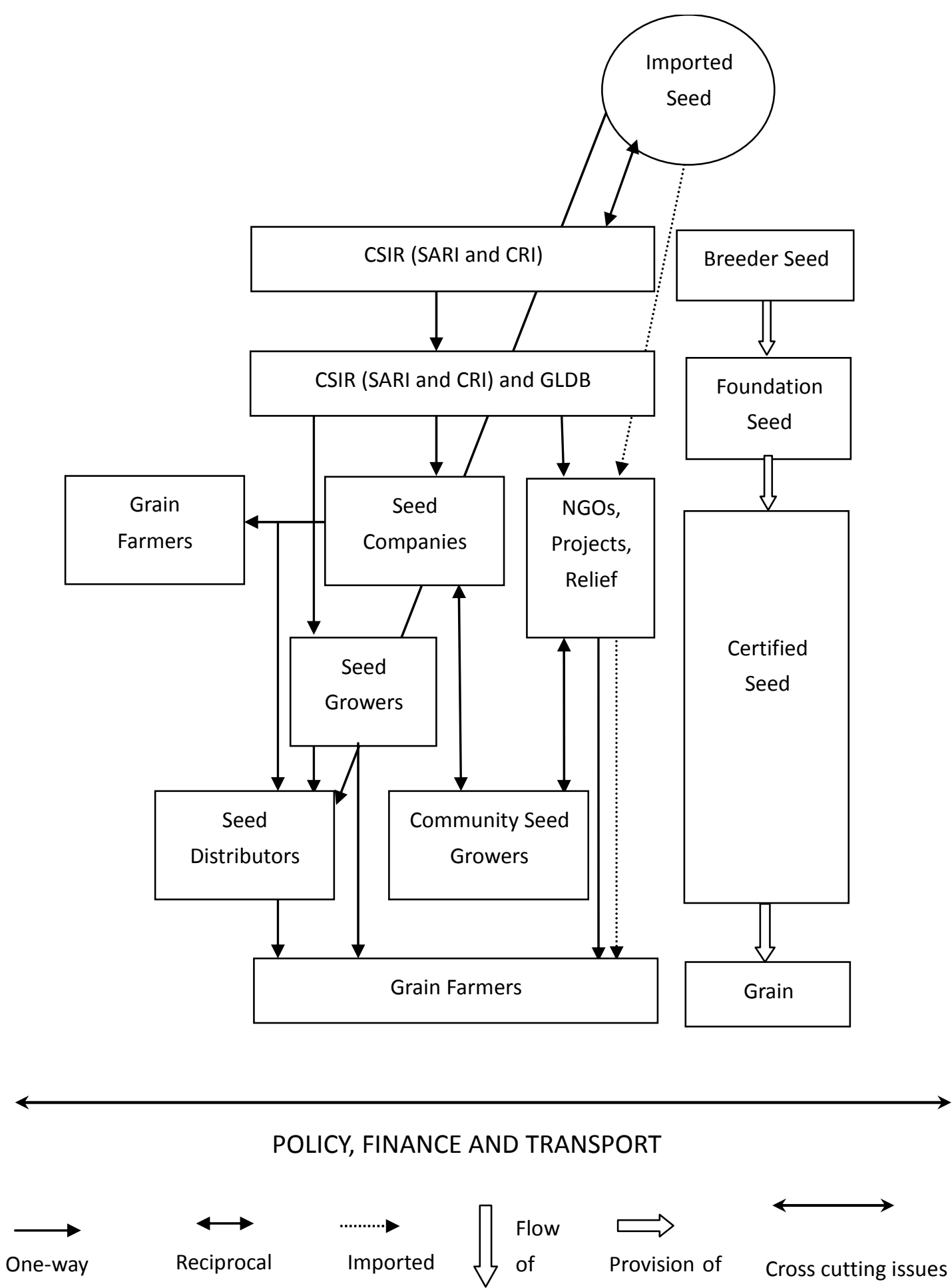

Figure 2. A flow chart of the seed delivery system in northern Ghana

\subsection{Smallholder Farmer's Preference for Improved Maize Seed Varieties}

Ten factors that are important in influencing the grain farmers' decision to use certified seeds were identified during the interviews had in the first phase of data collection. Grain farmers were then asked to rank these 10 factors during the second phase of the data collection. Results of the Kendall's Coefficient of Concordance for both the combined and regional dataset is presented in Table 4. Factors that are ranked highly by farmers have lower mean ranks and vice versa. 
Availability of certified seed, affordability, availability of a grain market, ability of certified seed to tolerant pest and disease, profitability of grain production and packaging of certified seed are the factors that were ranked highly by grain farmers as important in influencing their decision to utilize certified seed. Grain size, fertilizer requirement and maturity period were ranked as the least important factors. About a quarter $(24.8 \%)$ of the farmers agree with each other on their rankings. The level of agreement is highest among farmers in the Upper West Region (33.9\%) and lowest for farmer in the Northern Region $(28.8 \%)$ hence farmers in the latter region are more heterogeneous in their rankings.

Table 4. Factors that influences grain farmers' decision to use certified maize seed

\begin{tabular}{lcccc}
\hline & \multicolumn{2}{c}{ Mean Rank } & & \\
\cline { 2 - 5 } Characteristics & Northern & Upper West & Overall \\
& Region & Region & \\
\hline Seed availability & 3.41 & 4.30 & 3.90 & 3.51 \\
Affordability & 3.81 & 3.18 & 3.39 & 5.55 \\
Available grain market & 4.34 & 6.03 & 5.04 & 4.92 \\
Pest and disease resistance & 5.30 & 5.01 & 5.26 & 5.22 \\
Grain price/profitability & 4.67 & 5.81 & 6.05 & 5.28 \\
Packaging & 6.54 & 3.19 & 4.93 & 5.33 \\
Taste and nutrition & 5.32 & 6.54 & 6.30 & 5.85 \\
Grain size & 7.02 & 7.05 & 6.81 & 6.98 \\
Fertilizer requirement & 7.29 & 6.44 & 7.12 & 7.04 \\
Early maturity & 7.31 & 7.45 & 7.21 & 7.32 \\
\hline N & 105 & 50 & 49 & 204 \\
Kendall's Coefficient of Concordance & 0.288 & 0.304 & 0.339 & 0.248 \\
Chi-Square & 271.958 & 136.662 & 149.560 & 455.913 \\
Degrees of freedom & 9 & 9 & 9 & 9 \\
Asymp. Sig. & $<0.001$ & $<0.001$ & $<0.001$ & $<0.001$ \\
\hline
\end{tabular}

\subsection{Level of Adoption of Improved Maize Seed Varieties}

Seventy percent of the sampled grain farmers reported using improved maize varieties such as Obatanpa, Omankwa, Okomasa, Dorke and Aburohemaa. These varieties were all developed by the CSIR in collaboration with the International Institute of Tropical Agriculture (IITA) and International Centre for Maize and Wheat Improvement (CIMMYT). Even though some farmers reported cultivating improved varieties since those varieties were procured from formal sources, they did not readily know the names of the varieties. All varieties reported are open pollinated hence it is common for farmers to keep on recycling the seeds after initial purchase.

Improved maize varieties are generally high yielding with different maturity periods and are also tolerant to stresses such as drought and striga. In this study, only 30 percent of the farmers indicated that they use local maize varieties. Traditional varieties are usually full season landraces and tend to be well adapted to local conditions. According Wiredu et al. (2010), 95 percent of farmers in northern Ghana are using improved maize varieties. Ragasa et al. (2013) estimated that 61 percent of maize area in Ghana is cultivated with improved varieties. On the other hand, in Tanzania, Kassie et al. (2012) estimated an adoption rate of 76.5 percent of improved maize varieties. About 53 and 47 percent of well and poorly endowed households respectively, were reported to have adopted improved maize varieties in Ethiopia (Legese et al., 2009). In the coastal lowlands of Kenya, adoption of improved maize varieties was estimated to be 40 percent (Wekesa et al., 2003).

Northern Ghana is patrilineal in nature hence males are normally the household heads and therefore have access and control over household resources. Males often dominate farmer-based organisations and are usually leaders of communities and associations. Males appear to be dominating maize production with women playing critical roles in the farming process and dominating in post-harvest and marketing activities. The proportion of males who have adopted improved maize varieties $(90.8 \%)$ were significantly higher the proportion of males who are 
yet to adopt improved maize varieties (83.9\%). GSS, 2013 estimates that about $47 \%$ of agricultural household heads in Ghana have never had any form of formal education. Similarly, the farmer survey highlighted that 63 percent of farmers had no formal education. The proportion of educated farmers who have adopted improved maize varieties (21.8\%) is significantly higher than the educated farmers who are yet to adopt (16.1\%). Educated farmers are able to read basic instruction and appreciate seed characteristics. They usually act as the secretaries of farmer-based organisations and are often the favourites of extension workers especially those who do not understand the local dialects. An educated farmer is also more likely to have another occupation as well as seek for agricultural information. In this study, the mean household size of the respondents was found to be 14 . The size of the households may be as a result of the extended family system and polygamy. Household members are a source of family labour. The size of the household has implications on household food security and poverty. The finding of this study is higher than a recent estimate by GSS (2013) who reported a household size of 5 persons for rural households in Ghana. On average, farmers who are yet to adopt improved maize varieties had significantly large farm sizes ( 4.2 hectares) as compared to farmers who have adopted ( 3.1 hectares) certified maize seed. Farm size has implications on the amount of resources required for farm investment. MoFA (2011) reported that about 90 percent of agriculture in Ghana is on smallholder basis.

Results revealed a negative relationship between income and the use of improved maize varieties for farming. Many farmers with a relatively low income have adopted improved maize varieties compared to their higher income counterparts (Table 5). This could be due to their greater reliance on farming and use of better technologies that can improve their income levels. Furthermore, this could also be attributable to their access to improved maize seed varieties through agricultural projects and NGOs as these farmers are targeted by projects due to their vulnerability. A higher proportion of farmers who have adopted improved maize varieties also utilize certified cowpea (50.0\%) seed as compared to farmers who are yet to adopt $(33.3 \%)$. Farmers who cultivate certified cowpea seed are more likely to know the benefits of planting certified seeds. Such farmers are also more likely to be exposed to improved maize varieties since both seeds are usually sold by the same agro-input dealer. Extension workers often encourage farmers to rotate legumes with cereals such as maize. It is not uncommon for farmers to use incomes for cowpea production to invest on their maize farms.

Table 5. Socio-economic characteristics of grain farmers

\begin{tabular}{lcc}
\hline \multirow{2}{*}{ Variable } & \multicolumn{2}{c}{ Percent } \\
\cline { 2 - 3 } & Adopters & Non-Adopters \\
\hline Male & $90.8^{*}$ & $83.9^{*}$ \\
Formal education & $21.8^{*}$ & $16.1^{*}$ \\
Farm income below GH $\not 1000.00$ & 46.5 & 43.5 \\
Farm income of GHф1001-1500 & $26.8^{*}$ & $12.9^{*}$ \\
Farm income of GHф1501-2000 & $7^{*}$ & $14.5^{*}$ \\
Farm income of GHф2001-2500 & $4.2^{*}$ & $14.5^{*}$ \\
Cultivate certified cowpea seed & 50.0 & 33.3 \\
\hline & & 14.2 \\
\hline Household size (Number) & 14.0 & Mean \\
Farm size (ha) & $3.1^{*}$ & \\
\hline
\end{tabular}

* denotes statistical significance at less than $\mathrm{p}=0.05$

\subsection{Factors Influencing Adoption of Improved Maize Varieties}

The study utilizes the marginal effects of the logistic model to discuss the factors that influence the adoption of improved maize seed varieties. Result shows household size and farm size were the only factors that significantly influence farmers' decision to use certified maize seed (Table 6). The probability of using an improved maize variety increases marginally as household size increases by one more person. Farmers with large households are usually wealthy hence such farmers are usually capable of purchasing improved maize varieties. Also, there appears to be a direct relationship between household size and social interaction and networking hence as the household size increases, there is an increased possibility of members being exposed to improved maize varieties which is a necessary condition to adoption. 
In northern Ghana, farmers who have large households tend to be regarded highly and are usually opinion leaders hence such farmers are often the first point of contact in introducing communities to a new technology or variety. In addition, the likelihood of adopting improved maize varieties that are high yielding increases as household size increase as result of the need to provide food for additional household members. This result is consistent with Awotide et al. (2012) and Jaleta et al. (2013) who reported a positive and significant relationship between household size and adoption of improved rice varieties in Nigeria and Ethiopia respectively. Mignouna et al. (2010) and Kassie et al. (2012) did not however observe any significant relationship between family size and adoption of improved maize varieties. Legese et al. (2009) found out that family size and adoption of improved maize varieties were inversely related.

The likelihood of adopting improved maize varieties decreases marginally as farm size increases by an additional hectare. Putting an additional hectare of land under cultivation requires additional resources not only for seed but also chemicals, labour and farm operations. Most smallholder farmers are usually resource poor and are therefore unable to manage large farm sizes with their meagre resources. Smallholder farmers therefore try to minimize cost anytime they expand their farms by using traditional seed instead of buying certified seeds which are perceived to be expensive. Smallholder farmers without any alternative livelihood usually do not want to take risks in their farming activities hence in expanding their farms; they tend to cultivate their own saved seed since they are certain about them. Extension workers who promote the use of improved maize varieties also encourage intensification instead of putting more land under cultivation. Farmers who have adopted improved maize varieties are therefore less likely to put more land under cultivation and vice versa. Also as farm size increases, the probability of getting free and adequate improved maize varieties from friends, seed growers and project for the additional land decreases, hence such farmers may have to rely on their own seed.

The finding of this study is not consistent with Awotide et al. (2012) who observed a positive and significant relationship between farm size and intensity of adoption of improved rice varieties in Nigeria. The finding of this study however collaborates that of Legese et al. (2009) who observed that wealthy Ethiopian households are less likely to adopt improved maize varieties as farm size increases. A negative but insignificant relationship was also found between poorly endowed households and improved maize variety adoption. Farmers with smaller farm sizes are more likely to adopt improved maize varieties in order to increase their production unlike farmers with larger farm size who may able to meet their grain requirement by putting more land under cultivation instead of adopting improved maize varieties (Legese et al., 2009). Wekesa et al. (2003), Mignouna et al. (2010) and Jaleta et al. (2013) did not however observe any significant relationship between adoption of improved maize technologies and farm size.

Table 6. Marginal effects of factors influencing adoption of improved maize varieties

\begin{tabular}{|c|c|c|c|c|c|c|}
\hline \multirow{2}{*}{$\begin{array}{l}\text { Variable } \\
\text { Upper East Region }\end{array}$} & \multirow{2}{*}{$\begin{array}{l}\text { Marginal Effect } \\
0.0912\end{array}$} & \multirow{2}{*}{$\begin{array}{l}\text { Standard } \\
\text { Error }\end{array}$} & \multirow{2}{*}{$\begin{array}{l}\mathrm{Z} \\
0.83\end{array}$} & \multirow{2}{*}{$\begin{array}{l}P>|Z| \\
0.405\end{array}$} & \multicolumn{2}{|c|}{ [95\% Conf. Interval] } \\
\hline & & & & & -0.1233 & 0.3057 \\
\hline Upper West Region & 0.2059 & 0.1392 & 1.48 & 0.139 & -0.0670 & 0.4788 \\
\hline Gender & 0.1590 & 0.1489 & 1.07 & 0.286 & -0.1329 & 0.4508 \\
\hline Formal education & 0.0742 & 0.1073 & 0.69 & 0.489 & -0.1361 & 0.2844 \\
\hline Household size & 0.0191 & 0.0081 & 2.36 & 0.018 & 0.0032 & 0.0349 \\
\hline Income less than $\mathrm{GH} \not 1,000$ & 0.1950 & 0.1408 & 1.39 & 0.166 & -0.0809 & 0.4708 \\
\hline Income of GHф 1,001-1,500 & 0.0335 & 0.1303 & 0.26 & 0.797 & -0.2220 & 0.2889 \\
\hline Income of GH $\phi 1,501-2,000$ & -0.1903 & 0.1229 & -1.55 & 0.122 & -0.4312 & 0.0506 \\
\hline Income of $\mathrm{GH} \phi 2,001-2,500$ & -0.1127 & 0.1319 & -0.85 & 0.393 & -0.3712 & 0.1457 \\
\hline Farm size (ha) & -0.0444 & 0.0191 & -2.33 & 0.020 & -0.0818 & -0.0071 \\
\hline Cultivates certified cowpea seed & 0.1318 & 0.1017 & 1.3 & 0.195 & -0.0675 & 0.3310 \\
\hline Wald chi ${ }^{2}(11)$ & & 18.99 & & & & \\
\hline Prob $>\mathrm{chi}^{2}$ & & 0.0413 & & & & \\
\hline Pseudo $\mathrm{R}^{2}$ & & 0.1998 & & & & \\
\hline Log pseudo likelihood & & -38.913745 & & & & \\
\hline
\end{tabular}




\section{Conclusions and Recommendations}

The seed system in Ghana is made up of three main components; a formal seed system, an informal farmers' seed system and a quasi-formal seed system. Multiple seed delivery channels are described and Ghana Seed Inspection Division (GSID) of MoFA is the agency responsible for seed certification. Two institutes of the Council for Scientific and Industrial Research (CSIR), are the main sources of breeder and foundation seeds utilized by seed companies, registered seed producers and community seed growers to produce certified seeds. All seed starts with breeder seed production by CSIR except for imported seed.

Policy, finance and transport are issues affecting the seed delivery system in northern Ghana. Communication and information flows are working well among actors in the seed delivery system in northern Ghana when there are direct relationship with actors, however are weak among actors that do not have direct relationships. Constraints prioritised by CSIR include lack of irrigation facilities, inadequate storage facilities, and an unknown demand for breeder and foundation seed, inadequate human resource and absence of patent rights over released varieties. There are opportunities within the system which can be harnessed to strengthen the system and these include availability of large hectares of arable land and availability of development partners or donors.

Availability of certified seed, affordability, available grain market, tolerance to pest and disease, grain price and seed packaging are the factors that were ranked highly by farmers in considering to use certified seed. Early maturity, fertilizer requirement and grain size were ranked lowly. About 70 percent of the sampled grain farmers reported using improved maize varieties. The probability of using an improved maize variety increases marginally as household size increases. The likelihood of adopting improved maize varieties decreases marginally as farm size increases by an additional hectare.

The findings of this study have important policy implications. First, given the unclear relationship and minimal information flow among members of the seed delivery system, there is a need to build the capacity to vertically integrate players in building an effective seed delivery system for northern Ghana. Innovative platforms should be established in order to facilitate open communication and dialogue among all actors in the seed delivery system. These platforms could also serve as a channel for information flow and targets for development intervention.

Capacities of research scientists and breeders to develop more pest and disease tolerant varieties will be important as more improved varieties become available. The capacities of seed companies should be built to produce foundation seed as permitted by the seed law and also to employ breeders. The innovation among these actors should identify areas where cost could be minimized and open more outlets and package seeds in different sizes in order to make seeds readily available and affordable.

Following the passage of the seed legislation, there is now the need to establish the regulatory framework for effective implementation of this seed law. The plant breeder's bill currently under consideration of parliament should be fast tracked and passed into a law in order to enable breeders to have patent rights over varieties that they develop. In addition, the private sectors should be encouraged to partner GSID in order to effectively undertake seed testing and certification. GSID in collaboration with law enforcement agencies should be encouraged to fine, arrest and even prosecute unscrupulous persons who engage in the sale of counterfeit seeds. Secondly, the general constraints facing the most of the members of the seed delivery system are related to erratic rainfall pattern, lack of irrigational and storage facilities, lack of equipment and other member-specific constraints. There is the need for infrastructural development. Government in collaboration with development partners should consider providing many more irrigation, processing and storage facilities in northern Ghana with specific attention to CSIR. Seed distributors should also be supported to acquire storage and warehousing facilities.

\section{Acknowledgments}

Authors would like to acknowledge the Commonwealth Scientific and Industrial Research Organisation (CSIRO); West and Central African Council for Agricultural Research and Development (CORAF/WECARD) and Savanna Agricultural Research Institute of the Council for Scientific and Industrial Research (CSIR-SARI) for providing the required financial support in completing this study in Ghana and the Australia Awards Scholarship for providing a full scholarship to study in Australia.

I am highly indebted to Dr Peter Carberry, Dr Issoufou Kollo, Dr Ernest Asiedu, Dr Ibrahim D. K. Atokple, to Ms Rebecca Wright, Director of CSIR-SARI, Dr. S. K. Nutsugah, Mr Prince Maxwell Etwire and Mr Edward Martey for their support and time. I am also grateful to all the enumerators of CSIR-SARI for their support in the data collection. 


\section{References}

Almekinders, C. (2000). The importance of informal seed sector and its relation with the legislative framework' Technology and Agarian Development, Nieuwe Kanaal (pp. 4-5). Retrieved from http://citeseerx.ist.psu.edu/viewdoc/download?doi=10.1.1.195.468\&rep=rep1\&type=pdf

Almekinders, J. M., \& Louwaars. N. P. (2008). The importance of the farmers' seed system in a functional national seed sector. Journal of New Seeds, 4(2), 15-33. http://dx.doi.org/10.1300/J153v04n01_02

Awotide, B. A., Diagne, A., Wiredu, A. N., \& Ojehomon, V. E. (2012). Wealth status and agricultural technology adoption among smallholder rice farmers in Nigeria. International Journal of Sustainable Development, 5(2).

Baig, V. A., \&Akhtar, J. ( 2011). Supply chain: value configuration analysis approach, a case study. Vision, 15, 3251-266.

Cleaver, K. M. (1993). A strategy to develop agriculture in Sub-Saharan Africa and a focus for the World Bank. World Bank technical paper-Africa technical department series 2013, Washington D.C, USA. http://dx.doi.org/10.1596/0-8213-2420-9

Cromwell, E., Friis-Hansen, E., \& Turner, M. (1992). The seed sector in developing countries: a framework for performance analysis. Overseas Development Institute (ODI) working paper 65, London.

Cromwell, E. (1996). The seed sector in perspective, in governments farmers and seed in changing Africa (ed). Overseas Development Institute, CAB International, Wallingford, UK. (pp. 8-25).

Etwire, P. M., Atokple, I. D. K., Buah, S. S., Abdulai, A. L., Karikari, A. S., \& Asungre, P. (2013a). Analysis of the seed system in Ghana. International Journal of Advance Agricultural Research, 1(1), 7-13. http://www.bluepenjournals.org/ijaar

Ghana Statistical Service. (2008). Ghana Living Standards Survey Report of the Fifth Round, Accra, Ghana.(p. 131).

Ghana Statistical Service. (2011). Administrative map of Ghana, Ghana.

Ghana Statistical Service. (2013). Non-monetary poverty in Ghana. 2010 Population and housing census report. Retrieved

from http://www.statsghana.gov.gh/docfiles/2010phe/NonMonetary\%20Poverty\%20in\%20Ghana\%20\%2824-10$13 \% 29$.pdf

Greene H. W. (2003). Econometric Analysis (5th Ed.). Pearson Education, Inc., Upper Saddle River: New Jersey.

Gujarati, D. N. (2004). Basic econometrics. The McGraw-Hill Companies, Connecticut.

Horna, D., \& Nagarajan, L. (2010). Seed sector development in Ghana: case of rice and maize. IFPRI, Accra, Ghana. Retrieved from http://www.ifpri.org/sites/default/files/publications/gsswp36.pdf

IBM Corp. (2013). IBM SPSS Statistics for Windows (Version 22.0). Armonk, NY: IBM Corp.

Jaleta, M., Yirga, C., Kassie, M., De Groote, H., \& Shiferaw, B. (2013). Knowledge, adoption and use intensity of improved maize technology in Ethiopia. $4^{\text {th }}$ International Conference of the African Association of Agricultural Economics. Hammamet. $\quad$ Retrieved from http://ageconsearch.umn.edu/bitstream/161483/2/Moti\%20Jaleta\%2c\%20Chilot\%20Yirga\%20et\%20al.pdf

Kassie, M., Jaleta, M., Shiferaw, B., Mmbando, F., \& De Groote, H. (2012). Improved maize technologies and welfare outcomes in smallholder systems: evidence from application of parametric and non-parametric approaches. International Association of Agricultural Economists Triennial Conference, Foz do Iquacu, Brazil. Retrieved from http://ageconsearch.umn.edu/bitstream/128004/1/KassieMaize.pdf

Legese, G., Langyintuo, A. S., Mwangi, W., Jaleta, M., \& La Rovere, R. (2009). Household Resource Endowment and Determinant of Adoption of Drought Tolerant Maize Varieties: A Double-hurdle Approach. International Association of Agricultural Economists Conference, Beijing, China. Retrieved from http://ageconsearch.umn.edu/bitstream/51785/8/51785paper.pdf

Loch, D. S., \& Boyce, K. G. (2003). Balancing public and private sector roles in an effective seed supply system. Field Crops Research, 84, 105-122. http://dx.doi.org/10.1016/S0378-4290(03)00144-8

Louwaars, N. P. L., \& De Boef, W. S. (2012). Integrated seed sector development in Africa: a conceptual framework for creating coherence between practices, programs and policies. Journal of Crop Improvement, 


\section{6, 39-59. http://dx.doi.org/10.1080/15427528.2011.611277}

Mc Guire, S. (2001). Farmers' management of sorghum genetic resources in Ethiopia: a basis for participatory plant breeding?, Collaborative plant breeding : Integrating farmers' and Plant breeders' knowledge and practice (ed.), CABI, Wallingford: Oxon.

Mignouna, D. B., Mutabazi, K., Senkondo, E. M., \& Manyong, V. M. (2010). Adoption of a new maize and production efficiency in western Kenya. $3^{\text {rd }}$ African Association of Agricultural Economists and Agricultural Economists Association of South Africa conference. Cape Town, South Africa. Retrieved from http://ageconsearch.umn.edu/bitstream/96160/2/101.\%20Maize\%20production\%20efficiency\%20in\%20Ke nya.pdf

Ministry of Food and Agriculture. (2011). Statistics. Facts and figures 2010. Research and Information Directorate. Ghana.

Muthoni, J., \& Nyamongo, D. O. (2008). Seed system in Kenya and their relationship to on-farm conservation of food crops. Journal of New Seeds, 9(4), pp. 330-342. http://dx.doi.org/10.1080/15228860802492273

Ndjeunga, J. (2002). Local village seed systems and pearl millet seed quality in Niger. Expl Agric, 38, 149-162. http://dx.doi.org/10.1017/S0014479702000224

Niangado, O. (2010) Varietal developmental and seed system in West Africa: challenges and opportunities. Second Africa Rice Congress. Bamako, Mali. Retrieved from http://www.africarice.org/workshop/ARC/0p1\%20Niangado\%20fin.pdf

Pandey, A., Bisht, I. S., Bhat, K. V., \& Mehta, P. S. (2011). Role of informal seed system in promoting landrace diversity and their on-farm conservation: a case study of rice in Indian Himalayas. Journal of Genetic Resource Crop Evolution, 58, 1213-1224. http://dx.doi.org/10.1007/s10722-010-9654-5

Ragasa, C., Dankyi A., Acheampong P., Nimo-Wiredu A., Chapoto, A., Asamoah, M., \& Tripp, R. (2013). Pattern of adoption of improved maize technologies in Ghana, Ghana Strategy Support Program. International Food Policy Research Institute. Retrieved from http://www.ifpri.org/sites/default/files/publications/gsspwp36.pdf

Rao, C. N. (2004). Indian seed system and plant variety protection. Economic and Political Weekly, 39(8), $845-852$.

Tripp, R. (2003). How to cultivate a commercial seed sector. Overseas Development Institute London, 18(44).

Tripp, R. (2006). Strategies for seed system development in sub-Saharan Africa: A case of Kenya, Malawi, Zambia and Zimbabwe. ICRISAT Journal, 2, 1-47.

Tripp, R., \& Mensah-Bonsu A. (2013). Ghana's commercial seed sector. International Food Policy Research Institute. Retrieved from http://www.ifpri.org/sites/default/files/publications/gsspwp32.pdf

Wekesa, E., Mwangi, W., Verkuiji, H., Danda, K., \& De Groote, H. (2003). Adoption of maize production technologies in the coastal lowlands of Kenya. CIMMYT. Retrieved from http://ageconsearch.umn.edu/bitstream/56109/2/coastalKenya.pdf

Wiredu, A. N., Gyasi, K. O, Abdoulaye, T., Sanogo, D., \& Langyintuo, A. (2010). Characterisation of maize producing households in the northern region of Ghana. CIMMYT (pp. 4-24). Retrieved from http://libcatalog.cimmyt.org/download/cim/95612.pdf

\section{Copyrights}

Copyright for this articleis retained by the author(s), with first publication rights granted to the journal.

This is an open-access article distributed under the terms and conditions of the CreativeCommons Attribution license (http://creativecommons.org/licenses/by/3.0/). 